\title{
COMMENT
}

\section{Single-dose intraoperative radiotherapy during lumpectomy for breast cancer: an innovative patient-centred treatment}

\author{
Jayant S. Vaidya $\mathbb{D}^{1}{ }^{1}$, Max Bulsara ${ }^{1,2}$, Michael Baum ${ }^{1}$, Jeffrey S. Tobias ${ }^{3}$ on behalf of the TARGIT-A trial authors
}

In the randomised TARGIT-A trial, risk-adapted targeted intraoperative radiotherapy (TARGIT-IORT) during lumpectomy was noninferior to whole-breast external beam radiotherapy, for local recurrence. In the long-term, no difference was found in any breast cancer outcome, whereas there were fewer deaths from non-breast-cancer causes. TARGIT-IORT should be included in pre-operative consultations with eligible patients.

British Journal of Cancer (2021) 124:1469-1474; https://doi.org/10.1038/s41416-020-01233-5

\section{MAIN}

In 1996, the British Journal of Cancer published original work from our group, describing widespread spatial distribution of additional cancer foci in mastectomy specimens of patients who were otherwise suitable for breast conservation. ${ }^{1}$ We proposed that these foci may not be clinically relevant because of local recurrence after breast conservation occurs mainly at the site of primary tumour. The TARGIT-A randomised trial ${ }^{2}$ was firmly rooted in this initial observation, and compared risk-adapted single-dose targeted intraoperative radiotherapy (TARGIT-IORT) given during lumpectomy vs conventional whole-breast external beam radiotherapy (EBRT) in an international randomised non-inferiority trial.

The long-term results of the randomised TARGIT-A trial were recently published. ${ }^{3}$ They confirmed comparable long-term effectiveness of risk-adapted TARGIT-IORT and EBRT in terms of breast cancer control. At 5-years complete follow-up, for the primary outcome of absolute difference in raw local-recurrence rates was $1.16 \%$ with the upper $90 \%$ confidence limit of $1.99 \%$, confirming non-inferiority at the prespecified margin of $2.5 \%$. With long-term follow-up (median 9 years, maximum 19 years), no statistically significant difference was found in local or distant control of breast cancer, breast-preservation or breast cancer mortality. Deaths from causes other than breast cancer were significantly fewer in the TARGIT-IORT arm-HR $0.59(0.40-0.86)$ $P=0.005$, with 12-year rates being 5.41 vs $9.85 \%$, a reduction of $4.44 \%$.

In this commentary we would like to address a number of critical points.

(1) The first of these is to emphasise that TARGIT-A trial was not restricted only to patients with a very low risk of local recurrence. Participants had a much higher risk profile than with other trials of partial breast irradiation (PBI, Table $1^{3-11}$ ). These other trials restricted the trial entry much more stringently, only recruiting patients with the best prognostic features. By contrast, a substantial absolute number of patients in TARGIT-A, just like the Fast-Forward trial of shorter-course whole breast radiotherapy (Table 2$)^{12}$ were at higher risk of relapse: 1898 (83\%) were younger than 70 years, $366(16 \%)$ had tumours $>2 \mathrm{~cm}$ in size, $443(20 \%)$ patients had grade 3 cancers, 488 (22\%) patients had involved nodes and 426 (19\%) had ER- or PgR-negative tumours.

Similarly, patients in the three main trials comparing radiotherapy vs no-radiotherapy (Table 2-CALBG, BASO-II and PRIME-II), ${ }^{13-16}$ were again very highly selected for their low-recurrence risk. By contrast with TARGIT-A, they were strictly limited to those older than 65 or 70 years, with smaller, lower grade, node negative and ER-positive tumours. Despite this, the 5-year local-recurrence rates with 'no-radiotherapy' were 2-3 times higher than those seen with TARGIT-IORT (Table 2).

For the record, most patients in the TARGIT-A trial who had high-risk features did not receive supplemental EBRT after TARGIT-IORT as part of the risk-adapted approach. For example, supplemental EBRT was not given to $78 \%$ of Grade 3 , not given to $82 \%$ of ER-negative and not given to $63 \%$ of node-positive patients. Rather, the decision regarding use of supplemental EBRT was made for the individual patient by the treating multidisciplinary team, particularly bearing in mind the main indications of unexpected lobular cancer and positive margins. We regard this as a more patient-centred approach, which takes account of the individual patientspecific circumstances, including their preferences.

What does all this add up to? Data from the TARGIT-A trial suggest that $\mathrm{PBI}$ using this risk-adapted TARGIT-IORT approach is applicable to a breast cancer population more widely inclusive than those recruited in other PBI or 'noradiotherapy' trials. By having TARGIT-IORT during their lumpectomy, 8 out of 10 patients complete their radiotherapy right away, and the benefits include avoiding repeated hospital visits, ${ }^{17}$ a generally lower toxicity, and an improved quality of life. ${ }^{18-23}$

\footnotetext{
${ }^{1}$ Division of Surgery and Interventional Science, University College London, London, UK; ${ }^{2}$ Department of Biostatistics, University of Notre Dame, Fremantle, WA, Australia and ${ }^{3}$ Department of Clinical Oncology, University College London Hospitals, London, UK

Correspondence: Jayant S. Vaidya (jayantvaidya@gmail.com)

The TARGIT-A trial authors are listed above Acknowledgements.
}

Received: 9 October 2020 Revised: 4 December 2020 Accepted: 11 December 2020

Published online: 2 February 2021 
Table 1. Modern trials comparing partial breast irradiation with whole breast radiotherapy.

\begin{tabular}{|c|c|c|c|c|c|c|c|}
\hline & \multicolumn{2}{|c|}{ Intraoperative } & \multicolumn{3}{|c|}{ Post-operative $2^{\text {nd }}$ procedure interstitial } & \multicolumn{2}{|c|}{ Post-operative external beam } \\
\hline & $\begin{array}{c}\text { TARGIT-A } \\
\text { Risk-adapted } \\
\text { TARGIT- } \\
\text { IORT during } \\
\text { lumpectomy }\end{array}$ & $\begin{array}{c}\text { Electron } \\
\text { IORT } \\
\text { during } \\
\text { lumpectomy } \\
\text { ELIOT }\end{array}$ & $\begin{array}{l}\text { TARGIT-A } \\
\text { Delayed } \\
\text { second- } \\
\text { procedure } \\
\text { TARGIT- } \\
\text { IORT } \\
\end{array}$ & $\begin{array}{c}\text { Interstitial } \\
\text { wires x } 5 \\
\text { days } \\
\text { GEC- } \\
\text { ESTRO }\end{array}$ & $\begin{array}{l}\text { NSAPB- } \\
\text { B039 } \\
\text { Balloon } \\
(6 \% \text { of exp. } \\
\text { arm) }\end{array}$ & $\begin{array}{c}\text { NSAPB-B39/ } \\
\text { RAPID /Florence } \\
\text { 3DCRT } \\
\text { /IMRT }\end{array}$ & $\begin{array}{c}\text { IMRT } \\
\text { IMPORT- } \\
\text { Low }\end{array}$ \\
\hline $\begin{array}{l}\text { Patients } \\
\text { Total }\end{array}$ & 2298 & 1305 & 1153 & 1184 & 811 & $2193 / 1754 / 520$ & 1343 \\
\hline At 6-yr FU & 1967 & 676 & 1068 & 784 & 708 & $1915 / 1548 / 503$ & 661 \\
\hline KM curves to & 12 years & 9 years & 12 years & 6.5 years & 10 years & $10 / 9 / 10.5$ yrs & 7 years \\
\hline $\begin{array}{l}\text { Tumours } \\
\text { Grade } 3(\%) \\
\text { Pos. nodes (\%) }\end{array}$ & $\begin{array}{c}\text { Medium risk } \\
20 \% \\
22 \% \\
\end{array}$ & $\begin{array}{c}\text { Medium risk } \\
20 \% \\
26 \% \\
\end{array}$ & $\begin{array}{c}\text { Low risk } \\
6 \% \\
6.5 \% \\
\end{array}$ & $\begin{array}{c}\text { Low risk } \\
9 \% \\
0 \% \\
\end{array}$ & $\begin{array}{c}\text { Low risk } \\
1 \% \\
10 \% \\
\end{array}$ & $\begin{array}{c}\text { Low risk } \\
1 \% / 15 \% / 11 \% \\
10 \% / 1 \% / 10 \% \\
\end{array}$ & $\begin{array}{c}\text { Low risk } \\
9 \% \\
3 \% \\
\end{array}$ \\
\hline $\begin{array}{l}\text { 5-year Local } \\
\text { recurrence }\end{array}$ & $\begin{array}{c}2.11 \% \\
\text { Vs. } 0.95 \%\end{array}$ & $\begin{array}{c}\quad 4.4 \% \\
\text { vs. } 0.4 \%\end{array}$ & $\begin{array}{c}3.96 \% \\
\text { VS. } 1.05 \%\end{array}$ & $\begin{array}{c}1.44 \% \\
\text { vs. } 0.92 \%\end{array}$ & $\begin{array}{c}2.8 \% \\
\text { vs. } 2.1 \%\end{array}$ & $\begin{array}{c}2.8 / 2.3 / 2.5 \% \\
\text { vs } 2.1 / 1.7 / 1.3 \%\end{array}$ & $\begin{array}{c}0.5 \% \\
\text { vs. } 1.1 \%\end{array}$ \\
\hline $\begin{array}{l}\text { Non-inferiority } \\
\text { Margin and } \\
\text { whether } \\
\text { achieved? }\end{array}$ & $\begin{array}{c}2.5 \% \\
\text { (bkgr 6\%) } \\
\text { Non-inferior }\end{array}$ & $\begin{array}{c}\text { Equivalence } \\
\text { margin } 4.5 \% \\
(\text { bkgr } 3 \%) \\
(4.4 \% \mathrm{v} \\
0.4 \%)\end{array}$ & $\begin{array}{c}2.5 \% \\
\text { (bkgr 6\%) } \\
\text { No. } \\
\text { Non-inferior in } \\
\text { HR+HER-, ET }\end{array}$ & $\begin{array}{c}3 \% \\
(\text { bkgr } 4 \%) \\
\text { Non-inferior }\end{array}$ & $\begin{array}{c}\text { Not } \\
\text { equivalent }\end{array}$ & $\begin{array}{l}\text { NA/ } 2.75 \% \text { (bkgr } \\
4 \% \text { ) } 2 \% \text { (bkgr } 3 \% \text { ) } \\
\text { Not equivalent/Non- } \\
\text { inferior/Non-inferior }\end{array}$ & $\begin{array}{c}2.5 \% \\
\text { (bkgr } \\
2.5 \%) \\
\text { Non- } \\
\text { inferior } \\
\end{array}$ \\
\hline $\begin{array}{l}\text { Breast cancer } \\
\text { control similar } \\
\text { to WBRT? }\end{array}$ & Yes & No & Yes & Yes & No & $\mathrm{No} / \mathrm{Yes} / \mathrm{Yes}$ & Yes \\
\hline $\begin{array}{l}\text { Toxicity/ QOL } \\
\text { less or more } \\
\text { than WBRT? }\end{array}$ & $\begin{array}{l}\text { Less toxicity, } \\
\text { better QOL }\end{array}$ & Not reported & $\begin{array}{l}\text { Less toxicity, } \\
\text { better QOL }\end{array}$ & $\begin{array}{c}\text { Less } \\
\text { toxicity, but } \\
\text { wire-entry } \\
\text { scarring not } \\
\text { reported }\end{array}$ & $\begin{array}{l}\text { More } \\
\text { toxicity, } \\
\text { QOL not } \\
\text { reported }\end{array}$ & $\begin{array}{l}\text { Generally more } \\
\text { toxicity, QOL not } \\
\text { reported }\end{array}$ & $\begin{array}{l}\text { No major } \\
\text { difference }\end{array}$ \\
\hline $\begin{array}{l}\text { Deaths from } \\
\text { other causes } \\
\text { different? }\end{array}$ & $\begin{array}{l}\text { Sig. reduced } \\
\text { (HR0.59); by } \\
4.4 \% \text { at } 12 \mathrm{y}\end{array}$ & $\begin{array}{l}\text { No } \\
\text { significant } \\
\text { difference }\end{array}$ & $\begin{array}{l}\text { No } \\
\text { significant } \\
\text { difference }\end{array}$ & $\begin{array}{l}\text { No } \\
\text { significant } \\
\text { difference }\end{array}$ & $\begin{array}{c}\text { No } \\
\text { significant } \\
\text { difference }\end{array}$ & $\begin{array}{c}\text { No } \\
\text { significant } \\
\text { difference }\end{array}$ & $\begin{array}{c}\text { No } \\
\text { significant } \\
\text { difference }\end{array}$ \\
\hline $\begin{array}{l}\text { Significant } \\
\text { scatter } \\
\text { radiation to } \\
\text { vital organs? }\end{array}$ & No & $\begin{array}{l}\text { Possibly, if } \\
\text { lead shield is } \\
\text { not properly } \\
\text { used }\end{array}$ & No & Yes & Yes & Yes & Yes \\
\hline $\begin{array}{l}\text { Additional } \\
\text { hospital visits } \\
\text { and time? }\end{array}$ & $\begin{array}{c}\text { No additional } \\
\text { visits for } \mathbf{8 0 \%} \text {; } \\
20 \% \text { had } \\
\text { supplemental } \\
\text { WBRT }(\sim 16 \\
\text { half days })\end{array}$ & $\begin{array}{c}\text { No } \\
\text { additional } \\
\text { visits }\end{array}$ & $\begin{array}{l}\text { Additional } \\
\text { surgical } \\
\text { procedure for } 1 \\
\text { dose single } \\
\text { dose } \\
\mathbf{1} \text { full day } \\
\end{array}$ & $\begin{array}{l}\text { Additional } \\
\text { procedure } \\
10 \# \text { over } 5 \\
\text { days, } 2 \# \text { /day } \\
\text { as inpatient } \\
\mathbf{5} \text { full days } \\
\end{array}$ & $\begin{array}{l}\text { Additional } \\
\text { procedure } \\
10 \# \text { over } 8 \\
\text { days } 2 \# / \text { day } \\
\mathbf{5} \text { full days }\end{array}$ & $\begin{array}{c}\text { 10\# twice per day } \\
\text { over 5-8 days or } \\
5 \# \text { over } 2 \text { weeks } \\
5.5 \text { full days or } 6 \\
\text { half days over } 2 \text { wks }\end{array}$ & $\begin{array}{l}16 \text { hospital } \\
\text { visits } \\
\mathbf{1 6} \text { half- } \\
\text { days }\end{array}$ \\
\hline $\begin{array}{l}\text { Where is it } \\
\text { done? }\end{array}$ & $\begin{array}{l}\text { Standard OR } \\
\text { like c-arm } \\
\text { fluoroscopy }\end{array}$ & $\begin{array}{l}\text { Lead-lined } \\
\text { walls }\end{array}$ & $\begin{array}{l}\text { Standard OR } \\
\text { like c-arm } \\
\text { fluoroscopy }\end{array}$ & $\begin{array}{l}\text { Lead-lined } \\
\text { walls }\end{array}$ & $\begin{array}{l}\text { Lead-lined } \\
\text { walls }\end{array}$ & $\begin{array}{l}\text { Lead lined } \\
\text { bunker }\end{array}$ & $\begin{array}{l}\text { Lead lined } \\
\text { bunker }\end{array}$ \\
\hline $\begin{array}{l}\text { How it is } \\
\text { done? }\end{array}$ & $\begin{array}{l}\text { Given during } \\
\text { lumpectomy } \\
\text { surgery }\end{array}$ & $\begin{array}{c}\text { Given } \\
\text { during } \\
\text { lumpectomy } \\
\text { surgery. } \\
\text { Needs } \\
\text { extensive } \\
\text { dissection + } \\
\text { deep lead } \\
\text { shield }\end{array}$ & $\begin{array}{l}\text { Given as a } \\
\text { second- } \\
\text { procedure by } \\
\text { re-opening the } \\
\text { lumpectomy } \\
\text { wound }\end{array}$ & $\begin{array}{l}\text { Given as } \\
\text { second- } \\
\text { procedure } \\
\text { and } \\
\text { radioactive } \\
\text { wires remain } \\
\text { in place for } 4 \\
\text { days (in- } \\
\text { patient) }\end{array}$ & $\begin{array}{l}\text { Given as } \\
\text { second } \\
\text { procedure } \\
\text { and the } \\
\text { baloon } \\
\text { remains in } \\
\text { place for } 8 \\
\text { days (in- } \\
\text { patient) }\end{array}$ & $\begin{array}{l}\text { Given as twice daily } \\
\text { treatments over } 8 \\
\text { days or } 5 \text { non- } \\
\text { consecutive days } \\
\text { over } 2 \text { weeks }\end{array}$ & $\begin{array}{l}\text { Given as } \\
\text { daily doses } \\
\text { for } 15 \text { days } \\
\text { over } 3 \\
\text { weeks }\end{array}$ \\
\hline
\end{tabular}

For NSABP-39 overall LR used for balloon. External beam days includes half a day for planning. The very old or small trials with less than 500 patients or those with less than 5-year follow-up-from Leeds (EBRT over 28 days, $n=174$, published 2005) ${ }^{38}$ and Christie (EBRT 10 days, $n=708$, published 1995) ${ }^{39}$ both with worse outcome for $\mathrm{PBI}$, Budapest (interstitial wires twice a day over 7 days, $n=258$, published 2013) with similar outcome for $\mathrm{PBI}{ }^{40}$ and trials with no published cancer outcome data ${ }^{41}$ are not included in this table. Table reproduced and slightly modified from Vaidya, J.S., Bulsara, M., Baum, M. et al. Intraoperative radiotherapy for breast cancer: powerful evidence to change practice, Nature Reviews Clinical Oncology. https://doi.org/10.1038/s41571-021-00471-7 (2021). Numbers are for patients with invasive breast cancer.

bkgr expected background risk in the control arm, ET endocrine therapy, QOL quality of life. 
Table 2. Modern trials of no-radiotherapy, the trial of short course whole-breast radiotherapy and the TARGIT-A trial.

\begin{tabular}{|c|c|c|c|c|c|}
\hline & $\begin{array}{l}\text { CALGB No RT } \\
\text { vs WBRT }\end{array}$ & $\begin{array}{l}\text { BASO } 2 \text { No RT } \\
\text { vs WBRT }\end{array}$ & $\begin{array}{l}\text { PRIME } 2 \text { No RT } \\
\text { vs WBRT }\end{array}$ & $\begin{array}{l}\text { FAST-FORWARD WBRT vs } \\
\text { shorter WBRT }\end{array}$ & $\begin{array}{l}\text { TARGIT-A trial risk-adapted single- } \\
\text { dose TARGIT-IORT vs WBRT }\end{array}$ \\
\hline Number for comparison & 636 & 1135 & 1326 & 2562 & 2298 \\
\hline Number at 6-year follow-up & $<500$ & $\mathrm{~N} / \mathrm{A}$ & $<600$ & 1025 & 1967 \\
\hline Age limits & $\begin{array}{l}\geq 70 \\
0 \%<70\end{array}$ & $\begin{array}{l}\geq 65 \\
0 \%<65\end{array}$ & $\begin{array}{l}\geq 65 \\
0 \%<65\end{array}$ & $\begin{array}{l}>18 \\
84 \%<70\end{array}$ & $\begin{array}{l}\geq 45 \\
60 \%<65 \\
85 \%<70\end{array}$ \\
\hline T Size limits & $\leq 2 \mathrm{~cm}$ & $\leq 2 \mathrm{~cm}$ & $\leq 3 \mathrm{~cm}$ & $\mathrm{~T} 1-\mathrm{T} 3$ & $\leq 3.5 \mathrm{~cm}$ \\
\hline Grade limits & No info. & Grade 1 & $\begin{array}{l}\text { Grade } 1 \text { or } 2 \text {, only } 2 \% \\
\text { grade } 3\end{array}$ & $\begin{array}{l}\text { No restriction } \\
28 \% \text { grade } 3\end{array}$ & $\begin{array}{l}\text { No restriction } \\
20 \% \text { grade } 3\end{array}$ \\
\hline Nodes limits & Negative & Negative & Negative & $\begin{array}{l}\text { No-N1 } \\
19 \% \text { node positive }\end{array}$ & $\begin{array}{l}\text { No restriction } \\
22 \% \text { node positive }\end{array}$ \\
\hline LV invasion & No info. & Negative & Neg if Gr 3 & No restriction & No restriction \\
\hline ER status & Positive & Positive & Positive & No restriction & No restriction \\
\hline Additional hospital visits & 1 & 1 & 1 & $7-15$ & $\begin{array}{l}\text { None in } 80 \% \text { of cases; WBRT } \\
\text { recommended in } 20 \%\end{array}$ \\
\hline 5-year local-recurrence rates & 4 vs $1 \%$ & 6 vs $2 \%$ & $\begin{array}{l}4.1 \text { vs } 1.3 \% \\
\text { Difference } 2.9 \% \text { (upper } \\
95 \% C l \text { 4.8\%) }\end{array}$ & $\begin{array}{l}2.1 \text { vs } 1.4 \% \text { (including } 7 \% \text { post- } \\
\text { mastectomy radiotherapy) } \\
\text { No difference }\end{array}$ & $\begin{array}{l}2.11 \text { vs. } 0.95 \% \\
\text { Non-inferiority confirmed with } \\
\text { complete } 5 \text {-year follow-up } \\
\text { Difference } 1.16 \% \text { Upper } 90 \% \\
\text { Cl } 1.99 \%\end{array}$ \\
\hline $\begin{array}{l}\text { Long-term outcomes, more } \\
\text { than } 5 \text { years }\end{array}$ & $\begin{array}{l}10-y r \text { OS } 67 \\
\text { vs } 66 \% ; \\
\text { LR } 8 \text { vs } 2 \% ; \\
10-y r \text { LRFS } ~ 53 \\
\text { vs } \sim 61 \%\end{array}$ & $\begin{array}{l}10-y r \text { LRFS } \\
\sim 89 \text { vs } \sim 97 \%\end{array}$ & $\begin{array}{l}\text { 10-yr LR } 9.8 \% \text { vs } 0.9 \% \text {. } \\
\text { Binomial } 10 \text {-year } \\
\text { Non-breast cancer } \\
\text { deaths } 3.9 \% \text { vs } 6.1 \% \\
\text { and total deaths } \\
13.2 \% \text { vs } 12 \%\end{array}$ & Not available & $\begin{array}{l}\text { At median follow-up of } 9 \text { years (max } \\
19 \text { years): } \\
\text { No difference in local/distant } \\
\text { control/breast preservation/breast } \\
\text { cancer mortality } \\
\text { Significantly fewer deaths from } \\
\text { other causes ( } 5.41 \% \text { vs } 9.85 \% \text { at } \\
12 \text { years) }\end{array}$ \\
\hline $\begin{array}{l}\text { Significant scattered radiation } \\
\text { to vital organs? }\end{array}$ & No & No & No & Yes & No \\
\hline Mortality & No difference & No difference & No difference & No difference & $\begin{array}{l}\text { Significantly reduced non-BC } \\
\text { mortality with TARGIT-IORT } \\
\text { No difference in BC mortality }\end{array}$ \\
\hline Toxicity in experimental arm & Not reported & Not reported & Not reported & $\begin{array}{l}\text { Higher (e.g. breast induration/ } \\
\text { hardness) }\end{array}$ & Reduced \\
\hline $\begin{array}{l}\text { Quality of life with } \\
\text { experimental treatment }\end{array}$ & Not reported & Not reported & $\begin{array}{l}\text { Higher insomnia } \\
\text { No improvement in } \\
\text { QOL }\end{array}$ & Not reported & $\begin{array}{l}\text { Improved breast related QOL } \\
\text { Improved cosmetic outcome } \\
\text { Reduced pain }\end{array}$ \\
\hline
\end{tabular}

(2) An important statistical point relates to the use of Kaplan-Meier (K-M) curves. These are very informative if properly computed. The first step for estimating the risk of any event (e.g. local recurrence), is to categorise each patient into either having the event or not. The time-to-event is then used to plot a graph. This would work well if everyone's follow-up was the same and no one died, but this of course is never the case because patients are never recruited all at the same instant in any trial. The K-M model therefore uses a method called 'censoring', which means that a patient's data are used until the point when they were last seen. The assumption is that they are alive after they were last seen and continue to have a risk of having local recurrence. But, sadly, some patients die during follow-up, at which point this assumption is of course no longer true. So, when plotting $\mathrm{K}-\mathrm{M}$ estimates for local recurrence, one should not categorise patients who have died as 'censored'. Such a plot must include death as an event. $^{3}$ Both the plot and any estimate in which the dead have been censored are set in an imaginary world where there is a continual risk of local recurrence after death. Unfortunately, such graphs have frequently been published and are inevitably misleading to readers.

Here is an example to make this clearer. Let's look at the NSABP-B39 data. ${ }^{24}$ Their K-M graph of local recurrence shows that the chance of having local recurrence with $\mathrm{PBI}$ at 10 years is $4.6 \%$, therefore $95.4 \%$ of patients can be expected to be local-recurrence free. This immediately leads to a paradox because in fact, only $90.6 \%$ are alive at 10 years, so how can a larger number of patients $(95.4 \%)$ be around (alive) to be local-recurrence free? A further example comes from the CALGB trial, ${ }^{14}$ in which over $90 \%$ patients are estimated to be alive without local recurrence at 10 years, when in fact only $60 \%$ are actually alive. Thus, such a $\mathrm{K}-\mathrm{M}$ graph allegedly depicting local control over time is misleading.

For this reason both DATECAN ${ }^{25}$ (European) and STEEP ${ }^{26}$ (American) guidelines, rightly insist that death and local recurrence should both be included as clinical events for assessing local treatments for breast cancer.

Most importantly of all, patients naturally need to know the local control achieved by any new approach compared with the previous standard, which is precisely provided by the outcome of local-recurrence-free survival.

(3) Next, we would like to discuss the persistent finding of fewer non-breast cancer deaths with TARGIT-IORT, compared with whole-breast radiotherapy. The reduction was mainly due to fewer deaths from cardiovascular or lung problems and from other cancers and was not small in magnitude: $41 \%$ in relative terms and $4.4 \%$ at 12 years in absolute terms.

Randomisation, especially when the trial size is large, ensures that both known and unknown factors are well balanced. In the TARGIT-A trial, all known prognostic factors ${ }^{3}$ were well balanced, as well as age and body mass index $(\mathrm{BMI}){ }^{3}$ relevant for risks of cardiovascular ${ }^{27}$ and malignant disease. $^{28}$

This somewhat surprising observation is in fact consistent with the results of meta-analyses of randomised trials comparing partial breast irradiation with whole-breast irradiation. $^{29,30}$ It is well to remember that even modern 
radiotherapy increases cardiac and lung cancer mortality. ${ }^{31-35}$ This is particularly important in current or ex-smokers, ${ }^{31}$ in which a survival decrement of $6 \%$ is estimated over a 30 year period. This detriment is likely to outweigh any possible survival benefit from radiotherapy for these patients with early breast cancer. ${ }^{36}$

Perhaps even more important nowadays, in patients with screen-detected cancer, where the dangers of overtreatment are now so well recognised, ${ }^{37}$ we argue that it is both logical and in the patient's interest to use TARGIT-IORT, in order to minimise side effects.

(4) Finally, it is obvious that this work has special relevance during the current COVID-19 pandemic during which additional visits for radiotherapy consultations, planning and treatment all raise the risks to a vulnerable population as well as adding to pressures on an overstretched hospital system. TARGIT-IORT could help reduce these risks and save precious resources.

\section{Conclusion}

Using the approach of risk-adapted TARGIT-IORT in patients with early breast cancer avoids the inconvenience and toxicity of whole-breast radiotherapy in 8 out of every 10 patients. When compared with whole-breast radiotherapy in the randomised TARGIT-A trial, now with long-term follow up, no difference was found for any breast cancer outcomes, but there was a reduction in non-breast cancer mortality with TARGIT-IORT. Previous studies have shown that the other advantages include reduced breast pain, a better quality of life, ${ }^{18-23}$ a cosmetically superior outcome and reduced travelling time for the patient. ${ }^{17}$

Clinicians and patients in 38 countries (260 centres) have been adopting TARGIT-IORT since the publication of the first results, and over 45,000 patients have been treated so far. We believe that the long-term data, ${ }^{3}$ taken together with the many obvious benefits for the patient, provide compelling evidence to roll this out further.

Finally, all doctors in the UK are now obliged to follow the recently published GMC guidelines which underline the essential nature of adequate patient information-i.e. what they can reasonably expect to be told-in order to provide valid consent (https://www.gmc-uk.org/ethical-guidance/ethical-guidance-fordoctors/consent). This powerful principle is now fully enshrined in UK law (Montgomery v Lanarkshire Health Board, 2015).

\section{TARGIT-A TRIAL AUTHORS}

Jayant S. Vaidya', Max Buslara ${ }^{2}$, Michael Baum ${ }^{1}$, Frederik Wenz ${ }^{4}$, Samuele Massarut ${ }^{5}$, Steffi Pigorsch ${ }^{6}$, Michael Alvarado ${ }^{7}$, Michael Douek ${ }^{8}$, Christobel Saunders ${ }^{9}$, Henrik L. Flyger $^{10}$, Wolfgang Eiermann ${ }^{6}$, Chris Brew-Graves ${ }^{1}$, Norman R. Williams ${ }^{1}$, Ingrid Potyka', Nicholas Roberts ${ }^{1}$, Marcelle Bernstein ${ }^{11}$, Douglas Brown ${ }^{12}$, Elena Sperk ${ }^{4}$, Siobhan Laws $^{13}$, Marc Sütterlin ${ }^{14}$, Tammy Corica ${ }^{15}$, Steinar Lundgren ${ }^{16,17}$, Dennis Holmes $^{18}$, Lorenzo Vinante ${ }^{19}$, Fernando Bozza ${ }^{20}$, Montserrat Pazos ${ }^{21}$, Magali Le BlancOnfroy $^{22}$, Günther Gruber ${ }^{23}$, Wojciech Polkowski ${ }^{24}$, Konstantin J. Dedes ${ }^{25}$, Marcus Niewald $^{26}$, Jens Blohmer ${ }^{27}$, David McCready ${ }^{28}$, Richard Hoefer ${ }^{29}$, Pond Kelemen ${ }^{30}$, Gloria Petralia ${ }^{31}$, Mary Falzon ${ }^{3,32}$, David J. Joseph ${ }^{15}$, Jeffrey S. Tobias ${ }^{3}$

${ }^{4}$ Department of Radiation Oncology, University Medical Centre Mannheim, Medical Faculty Mannheim, Heidelberg University, Heidelberg, Germany; ${ }^{5}$ Department of Surgery, Centro di Riferimento Oncologico di Aviano (CRO) IRCCS, Aviano, Italy; ${ }^{6}$ Department of Gynaecology and Obstetrics, Red Cross Hospital, Technical University of Munich, Munich, Germany; ${ }^{7}$ Department of Surgery, University of California, San Francisco, CA, USA; ${ }^{8}$ Nuffield Department of Surgical Sciences, University of Oxford, Oxford, UK; ${ }^{9}$ School of Surgery, University of Western Australia, Crawley, WA, Australia; ${ }^{10}$ Department of Breast Surgery, University of Copenhagen, Copenhagen, Denmark; ${ }^{11}$ London, UK; ${ }^{12}$ Department of Surgery, Ninewells Hospital, Dundee, UK; ${ }^{13}$ Department of Surgery, Royal Hampshire County Hospital, Winchester, UK; ${ }^{14}$ Department of Gynaecology and Obstetrics, University Medical Centre Mannheim, Medical Faculty Mannheim, Heidelberg University, Heidelberg, Germany; ${ }^{15}$ Department of Radiation Oncology, Sir Charles Gairdner Hospital, Perth, WA, Australia; ${ }^{16}$ Department of Oncology, St Olav's University Hospital, Trondheim, Norway; ${ }^{17}$ Department of Clinical and Molecular Medicine, Norwegian University of Science and Technology, Trondheim, Norway; ${ }^{18}$ University of Southern California, John Wayne Cancer Institute \& Helen Rey Breast Cancer Foundation, Los Angeles, CA, USA; ${ }^{19}$ Department of Radiation Oncology, Centro di Riferimento Oncologico di Aviano (CRO) IRCCS, Aviano, Italy; ${ }^{20}$ Veneto Institute of Oncology IOV - IRCCS, Padua, Italy; ${ }^{21}$ Department of Radiation Oncology, University Hospital, The Ludwig Maximilian University of Munich, Munich, Germany; ${ }^{22}$ Radiotherapy-Oncology, Western Cancer Institute, Nantes, France; ${ }^{23}$ Breast Centre Seefeld, Zurich, Switzerland; ${ }^{24}$ Department of Surgical Oncology, Medical University of Lublin, Lublin, Poland; ${ }^{25}$ Breast Centre, University Hospital Zurich, Zurich, Switzerland; ${ }^{26}$ Saarland University Medical Center, Homberg, Germany; ${ }^{27}$ Sankt Gertrauden Hospital, Charité, Medical University of Berlin, Berlin, Germany; ${ }^{28}$ Princess Margaret Cancer Centre, Toronto, ON, Canada; ${ }^{29}$ Sentara Surgery Specialists, Hampton, VA, USA; ${ }^{30}$ Ashikari Breast Center, New York Medical College, New York, NY, USA; ${ }^{31}$ Department of Surgery, University College London Hospitals, London, UK and ${ }^{32}$ Department of Pathology, University College London Hospitals, London, UK

\section{ACKNOWLEDGEMENTS}

NA

\section{AUTHOR CONTRIBUTIONS}

J.S.V. wrote the first draft, made important intellectual contribution to the conceptualisation, data analysis, data interpretation, writing and editing the manuscript and agreed with the final version. M.Bu. made important intellectual contributions towards conceptualisation, data analysis, data interpretation, writing and editing. M.Ba. and J.S.T. made important intellectual contribution towards conceptualisation, data interpretation, writing and editing. J.S.V., M.Bu., M.Ba. and J.S. T. agreed with the final version of the manuscript.

\section{ADDITIONAL INFORMATION}

Ethical approval and consent to participate or publish Not applicable.

Consent to publish Not applicable.

Data availability Not applicable.

Competing interests We declare support from University College London Hospitals (UCLH)/UCL Comprehensive Biomedical Research Centre, UCLH Charities, National Institute for Health Research (NIHR) Health Technology Assessment (HTA) programme, Ninewells Cancer Campaign, National Health and Medical Research Council, and Cancer Research Campaign (now Cancer Research UK) for the submitted work; J. S.V. has received a research grant from Photoelectron Corp (1996-1999) and from Carl Zeiss for supporting data management at the University of Dundee (Dundee, UK, 2004-2008), and has received honorariums. J.S.V., J.S.T. and M.B.u. receive funding from HTA, NIHR, Department of Health and Social Care for some activities related to the TARGIT trials. M.B.a. was briefly on the scientific advisory board of Carl Zeiss and was paid consultancy fees before 2010. All authors received some travel support from Carl Zeiss. Carl Zeiss had no role in concept, design, analysis or writing of the manuscript.

Funding information No specific funding was made available for this paper. The TARGIT-A trial was sponsored by University College London Hospitals (UCLH)/UCL Comprehensive Biomedical Research Centre. Funding was provided by UCLH Charities, National Institute for Health Research (NIHR) Health Technology Assessment programme (HTA 07/60/49), Ninewells Cancer Campaign, National Health and Medical Research Council, and German Federal Ministry of Education and Research (BMBF) FKZ 01ZP0508. The infrastructure of the trial operations office in London, UK was supported by core funding from Cancer Research Campaign (now Cancer Research UK) when the trial was initiated. The funding organisations had no role in concept, design, analysis or writing of the manuscript.

Publisher's note Springer Nature remains neutral with regard to jurisdictional claims in published maps and institutional affiliations.

\section{REFERENCES}

1. Vaidya, J. S., Vyas, J. J., Chinoy, R. F., Merchant, N., Sharma, O. P. \& Mittra, I. Multicentricity of breast cancer: whole-organ analysis and clinical implications. $B r$. J. Cancer 74, 820-824 (1996). 
2. Vaidya, J. S., Wenz, F., Bulsara, M., Tobias, J. S., Joseph, D., Saunders, C. et al. An international randomised controlled trial to compare targeted intra-operative radiotherapy (TARGIT) with conventional post-operative radiotherapy after conservative breast surgery for women with early stage breast cancer (The TARGIT-A trial). Health Technol. Assess. 20, 1-226 (2016).

3. Vaidya, J. S., Bulsara, M., Baum, M., Wenz, F., Massarut, S., Pigorsch, S. et al. Long term survival and local control outcomes from single dose targeted intraoperative radiotherapy during lumpectomy (TARGIT-IORT) for early breast cancer: TARGIT-A randomised clinical trial. BMJ 370, m2836 (2020).

4. Veronesi, U., Orecchia, R., Maisonneuve, P., Viale, G., Rotmensz, N., Sangalli, C. et al. Intraoperative radiotherapy versus external radiotherapy for early breast cancer (ELIOT): a randomised controlled equivalence trial. The Lancet Oncology 14, 1269-1277 (2013).

5. Vaidya, J. S., Bulsara, M., Saunders, C., Flyger, H., Tobias, J. S., Corica, T. et al. Effect of delayed targeted intraoperative radiotherapy vs whole-breast radiotherapy on local recurrence and survival. JAMA Oncology 6, e200249 (2020).

6. Strnad, V., Ott, O. J., Hildebrandt, G., Kauer-Dorner, D., Knauerhase, H., Major, T. et al. 5-year results of accelerated partial breast irradiation using sole interstitial multicatheter brachytherapy versus whole-breast irradiation with boost after breast-conserving surgery for low-risk invasive and in-situ carcinoma of the female breast: a randomised, phase 3, non-inferiority trial. The Lancet $\mathbf{3 8 7}$, 229-238 (2016)

7. Vicini, F. A., Cecchini, R. S., White, J. R., Arthur, D. W., Julian, T. B., Rabinovitch, R. A. et al. Long-term primary results of accelerated partial breast irradiation after breast-conserving surgery for early-stage breast cancer: a randomised, phase 3 , equivalence trial. The Lancet 394, 2155-2164 (2019).

8. Whelan, T. J., Julian, J. A., Berrang, T. S., Kim, D.-H., Germain, I., Nichol, A. M. et al. External beam accelerated partial breast irradiation versus whole breast irradiation after breast conserving surgery in women with ductal carcinoma in situ and node-negative breast cancer (RAPID): a randomised controlled trial. The Lancet 394, 2165-2172 (2019).

9. Meattini, I., Marrazzo, L., Saieva, C., Desideri, I., Scotti, V., Simontacchi, G. et al. Accelerated partial-breast irradiation compared with whole-breast irradiation for early breast cancer: long-term results of the randomized Phase III APBI-IMRTFlorence trial. J. Clin. Oncol. 38, 4175-4183 (2020).

10. Coles, C. E., Griffin, C. L., Kirby, A. M., Titley, J., Agrawal, R. K., Alhasso, A. et al. Partial-breast radiotherapy after breast conservation surgery for patients with early breast cancer (UK IMPORT LOW trial): 5-year results from a multicentre, randomised, controlled, phase 3, non-inferiority trial. The Lancet 390, 1048-1060 (2017).

11. Vaidya, J. S., Bulsara, M. \& Baum, M. Targeted intraoperative radiotherapy for early breast cancer-reply. JAMA Oncology 6, 1637 (2020).

12. Brunt, A. M., Haviland, J. S., Wheatley, D. A., Sydenham, M. A., Alhasso, A., Bloomfield, D. J. et al. Hypofractionated breast radiotherapy for 1 week versus 3 weeks (FAST-Forward): 5-year efficacy and late normal tissue effects results from a multicentre, non-inferiority, randomised, phase 3 trial. The Lancet 395, 1613-1626 (2020).

13. Hughes, K. S., Schnaper, L. A., Berry, D., Cirrincione, C., McCormick, B., Shank, B. et al. Lumpectomy plus tamoxifen with or without irradiation in women 70 years of age or older with early breast cancer. N. Engl. J. Med. 351, 971-977 (2004).

14. Hughes, K. S., Schnaper, L. A., Bellon, J. R., Cirrincione, C. T., Berry, D., McCormick, $B$. et al. Lumpectomy plus tamoxifen with or without irradiation in women age 70 years or older with early breast cancer: long-term follow-up of CALGB 9343. J. Clin. Oncol. 31, 2382-2387 (2013).

15. Kunkler, I. H., Williams, L. J., Jack, W. J., Cameron, D. A. \& Dixon, J. M., investigators, P. I. Breast-conserving surgery with or without irradiation in women aged 65 years or older with early breast cancer (PRIME II): a randomised controlled trial. Lancet Oncol. 16, 266-273 (2015) and updated at San Antonio Breast Cancer Symposium, Dec 2020.

16. Blamey, R. W., Bates, T., Chetty, U., Duffy, S. W., Ellis, I. O., George, D. et al. Radiotherapy or tamoxifen after conserving surgery for breast cancers of excellent prognosis: British Association of Surgical Oncology (BASO) II trial. Eur. J. Cancer 49, 2294-2302 (2013).

17. Coombs, N. J., Coombs, J. M., Vaidya, U. J., Singer, J., Bulsara, M., Tobias, J. S. et al. Environmental and social benefits of the targeted intraoperative radiotherapy for breast cancer: data from UK TARGIT-A trial centres and two UK NHS hospitals offering TARGIT IORT. BMJ Open 6, e010703 (2016).

18. Sperk, E., Welzel, G., Keller, A., Kraus-Tiefenbacher, U., Gerhardt, A., Sutterlin, M. et al. Late radiation toxicity after intraoperative radiotherapy (IORT) for breast cancer: results from the randomized phase III trial TARGIT A. Breast Cancer Res. Treat. 135, 253-260 (2012).

19. Welzel, G., Boch, A., Sperk, E., Hofmann, F., Kraus-Tiefenbacher, U., Gerhardt, A. et al. Radiation-related quality of life parameters after targeted intraoperative radiotherapy versus whole breast radiotherapy in patients with breast cancer: results from the randomized phase III trial TARGIT-A. Radiat. Oncol. 8, 9 (2013).

20. Andersen, K. G., Gartner, R., Kroman, N., Flyger, H. \& Kehlet, H. Persistent pain after targeted intraoperative radiotherapy (TARGIT) or external breast radiotherapy for breast cancer: a randomized trial. Breast 21, 46-49 (2012).

21. Keshtgar, M. R., Williams, N. R., Bulsara, M., Saunders, C., Flyger, H., Cardoso, J. S. et al. Objective assessment of cosmetic outcome after targeted intraoperative radiotherapy in breast cancer: results from a randomised controlled trial. Breast Cancer Res. Treat. 140, 519-525 (2013).

22. Corica, T., Nowak, A. K., Saunders, C. M., Bulsara, M., Taylor, M., Vaidya, J. S. et al. Cosmesis and breast-related quality of life outcomes after intraoperative radiation therapy for early breast cancer: a substudy of the TARGIT-A trial. Int. J. Radiat. Oncol. Biol. Phys. 96, 55-64 (2016).

23. Corica, T., Nowak, A. K., Saunders, C. M., Bulsara, M. K., Taylor, M., Williams, N. R. et al. Cosmetic outcome as rated by patients, doctors, nurses and BCCT.core software assessed over 5 years in a subset of patients in the TARGIT-A trial. Radiat. Oncol. 13, 68 (2018).

24. Vicini, F. A., Cecchini, R. S., White, J. R., Arthur, D. W., Julian, T. B., Rabinovitch, R. A et al. Long-term primary results of accelerated partial breast irradiation after breast-conserving surgery for early-stage breast cancer: a randomised, phase 3 , equivalence trial. Lancet 394, 2155-2164 (2019).

25. Gourgou-Bourgade, S., Cameron, D., Poortmans, P., Asselain, B., Azria, D., Cardoso, F. et al. Guidelines for time-to-event end point definitions in breast cancer trials: results of the DATECAN initiative (Definition for the Assessment of Time-to-event Endpoints in CANcer trials)dagger. Ann. Oncol. 26, 873-879 (2015).

26. Hudis, C. A., Barlow, W. E., Costantino, J. P., Gray, R. J., Pritchard, K. I., Chapman, J. A. et al. Proposal for standardized definitions for efficacy end points in adjuvant breast cancer trials: the STEEP system. J. Clin. Oncol. 25, 2127-2132 (2007).

27. Van Gaal, L. F., Mertens, I. L. \& De Block, C. E. Mechanisms linking obesity with cardiovascular disease. Nature 444, 875-880 (2006).

28. Keum, N., Greenwood, D. C., Lee, D. H., Kim, R., Aune, D., Ju, W. et al. Adult weight gain and adiposity-related cancers: a dose-response meta-analysis of prospective observational studies. J. Natl Cancer Inst. 107, djv088 (2015).

29. Vaidya, J. S., Bulsara, M., Wenz, F., Coombs, N., Singer, J., Ebbs, S. et al. Reduced mortality with partial-breast irradiation for early breast cancer: a meta-analysis of randomized trials. Int. J. Radiat. Oncol. Biol. Phys. 96, 259-265 (2016).

30. Vaidya, J. S., Bulsara, M., Wenz, F., Tobias, J. S., Joseph, D. \& Baum, M. Targeted radiotherapy for early breast cancer. Lancet 391, 26-27 (2018).

31. Taylor, C., Correa, C., Duane, F. K., Aznar, M. C., Anderson, S. J., Bergh, J. et al. Estimating the risks of breast cancer radiotherapy: evidence from modern radiation doses to the lungs and heart and from previous randomized trials. $J$. Clin. Oncol. 35, 1641-1649 (2017).

32. Darby, S. C., Ewertz, M., McGale, P., Bennet, A. M., Blom-Goldman, U., Brønnum, D. et al. Risk of ischemic heart disease in women after radiotherapy for breast cancer. N. Engl. J. Med. 368, 987-998 (2013).

33. Burt, L. M., Ying, J., Poppe, M. M., Suneja, G. \& Gaffney, D. K. Risk of secondary malignancies after radiation therapy for breast cancer: comprehensive results. Breast 35, 122-129 (2017).

34. Grantzau, T. \& Overgaard, J. Risk of second non-breast cancer after radiotherapy for breast cancer: a systematic review and meta-analysis of 762,468 patients. Radiother. Oncol. 114, 56-65 (2015).

35. Bansod, S. \& Desai, R. Nationwide prevalence and trends of acute cardiovascular and cerebrovascular events among adult breast cancer survivors with a history of radiation therapy. Breast Cancer Res. Treat. 180, 267-268 (2020).

36. Early Breast Cancer Trialists' Collaborative, G. Effects of radiotherapy and of differences in the extent of surgery for early breast cancer on local recurrence and 15-year survival: an overview of the randomised trials. Lancet 366, 2087-2106 (2005).

37. Marmot, M., Altman, D. G., Cameron, D. A., Dewar, J. A., Thompson, S. G. \& Wilcox, $M$. Independent UK panel on breast cancer screening replies to Michael Baum. BMJ 346, f873 (2013).

38. Dodwell, D. J., Dyker, K., Brown, J., Hawkins, K., Cohen, D., Stead, M. et al. A randomised study of whole-breast vs tumour-bed irradiation after local excision and axillary dissection for early breast cancer. Clin. Oncol. 17, 618-622 (2005).

39. Ribeiro, G. G., Magee, B., Swindell, R., Harris, M. \& Banerjee, S. S. The Christie Hospital breast conservation trial: an update at 8 years from inception. Clin. Oncol. 5, 278-283 (1993).

40. Polgar, C., Fodor, J., Major, T., Sulyok, Z. \& Kasler, M. Breast-conserving therapy with partial or whole breast irradiation: ten-year results of the Budapest randomized trial. Radiother. Oncol. 108, 197-202 (2013).

41. Yadav, B. S., Loganathan, S., Sharma, S. C., Singh, R. \& Dahiya, D. Comparison of toxicity and cosmetic outcomes after accelerated partial breast irradiation or whole breast irradiation using 3-dimensional conformal external beam radiation therapy. Adv. Radiat. Oncol. 5, 171-179 (2020). 
Single-dose intraoperative radiotherapy during lumpectomy for breast...

JS Vaidya et al.

1474

(c) (1) Open Access This article is licensed under a Creative Commons Attribution 4.0 International License, which permits use, sharing, adaptation, distribution and reproduction in any medium or format, as long as you give appropriate credit to the original author(s) and the source, provide a link to the Creative Commons license, and indicate if changes were made. The images or other third party material in this article are included in the article's Creative Commons license, unless indicated otherwise in a credit line to the material. If material is not included in the article's Creative Commons license and your intended use is not permitted by statutory regulation or exceeds the permitted use, you will need to obtain permission directly from the copyright holder. To view a copy of this license, visit http://creativecommons. org/licenses/by/4.0/.

() The Author(s) 2021 